\title{
Cultivation cost-benefit analysis of some important medicinal plants in Serbia
}

\author{
Dejan Pljevljakušić ${ }^{*}$ and SReta Brkić ${ }^{1}$ \\ ${ }^{1}$ Institute for Medicinal Plants Research „Dr. Josif Pančić“, Tadeuša Košćuška 1, 11000 Belgrade, Serbia \\ *Corresponding author:dpljevljakusic@mocbilja.rs
}

Received: June 3, 2020

Accepted: November 15, 2020

Published on-line: December 15, 2020

Published: December 25, 2020

\begin{abstract}
Driven by frequent misinformation about the level of profitability of growing certain medicinal plants, in this paper we presented a cost-benefit analysis based on twenty years of experience in field production. The observed costs and profits for peppermint, chamomile, lemon balm, marshmallow, valerian and pot marigold are based on the average values of production elements within the current prices of labor, energy and raw materials. Fixed costs in this paper were deliberately neglected and the discussion was based on the assumption of the existence and availability of infrastructure. In the cost analysis, we divided them into four main groups, which had different shares in total costs such as labor (45-79\%), drying (5-37\%), material (9-16\%) and machinery use (4-13\%). Regarding the level of profitability of cultivation of the six observed medicinal plants valerian was the most profitable with an estimated profit of over $4000 € /$ ha. Next best earning plants were lemon balm and marshmallow with about $3500 € /$ ha, while the income from peppermint and chamomile was more than twice lower and it was around $1500 € / \mathrm{ha}$. The lowest profit was realized by cultivating marigold (about $600 € / \mathrm{ha}$ ) due to the high labor consumption on the flower picking operation. In terms of labor consumption marshmallow, pot marigold and valerian are the most demanding with 365,285 and 150 working days per hectare, respectively. The general conclusion of this observation of the profitability of growing medicinal plants would be that the producer must be aware of the costs and scope of labor engagement which should be expected per unit area before embarking on the calculation of production.
\end{abstract}

Key words: herbs, medicinal plants, cultivation, economy, cost, benefit, labor

\section{INTRODUCTION}

Non-scientific literature and other media information about the profitability of growing medicinal plants can often be too affirmative, bringing a potential new producer into trouble when faced with real production costs. Unlike conventional crops, the cultivation of medicinal plants is characterized by certain specifics that new producers usually do not recognize at the beginning of the production calculation. The main differences are reflected in the amount of labor and drying energy costs (Müller and Heindl, 2006; Raghu, 2018). In addition to this, attention should be paid also to the costs of storage and transport since the raw material of medicinal herbs is bulky (Cunningham, 1994).

Not every medicinal plant on the market is suitable for cultivation. Successful cultivation of alochtonous plants requires information on the adaptation of species to regions outside their natural habitats (Raghu, 2018). Among medicinal plant species that are in use in Europe, only $10 \%$ are commercially cultivated (Lange, 1998; Vines, 2004). Schippmann et al. (2003) stated that the economic calculation is the decisive link to bring a species into cultivation, which is strongly influenced by the price and availability of the same plants in nature. Medicinal plant cultivation benefit is compromised as long as sufficient volumes of plant material can still be obtained at a lower price from wild harvest. Dajić Stevanović and Pljevljakušić (2015) have summarized the most common issues with which the producers of medicinal plants encountered in seven topics such as (i) market, (ii) abundance and accessibility of wild populations, (iii) agro-environmental conditions, (iv) labor availability and costs, (v) investments in machinery, (vi) post-harvest processing, and (vii) rationality of production. In Serbia there are about 2000 ha under cultivation of medicinal plants (CCIS report, 2018).

Market demand fluctuations for specific medicinal plant species are usually affected by species abundance in nature, the population of available collectors, and the profitability of cultivation (Schippmann et al., 2006; Small, 2004). The wildcrafting of medicinal plants have much lower costs compared to expenses that filed production has. Comparing medicinal 

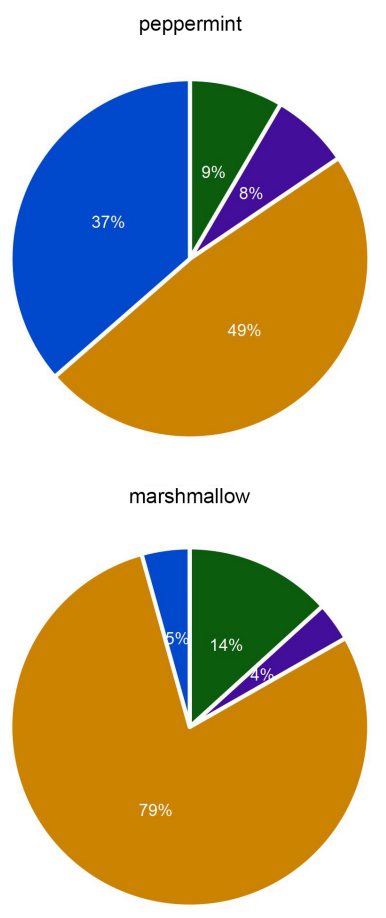

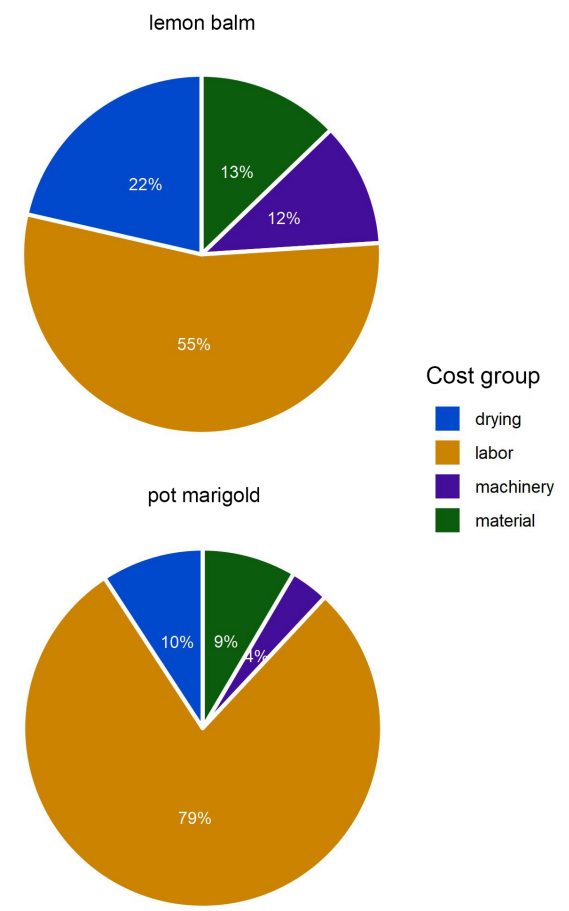

Fig. 1. The main groups of cultivation costs of six medicinal plants grown in Serbia

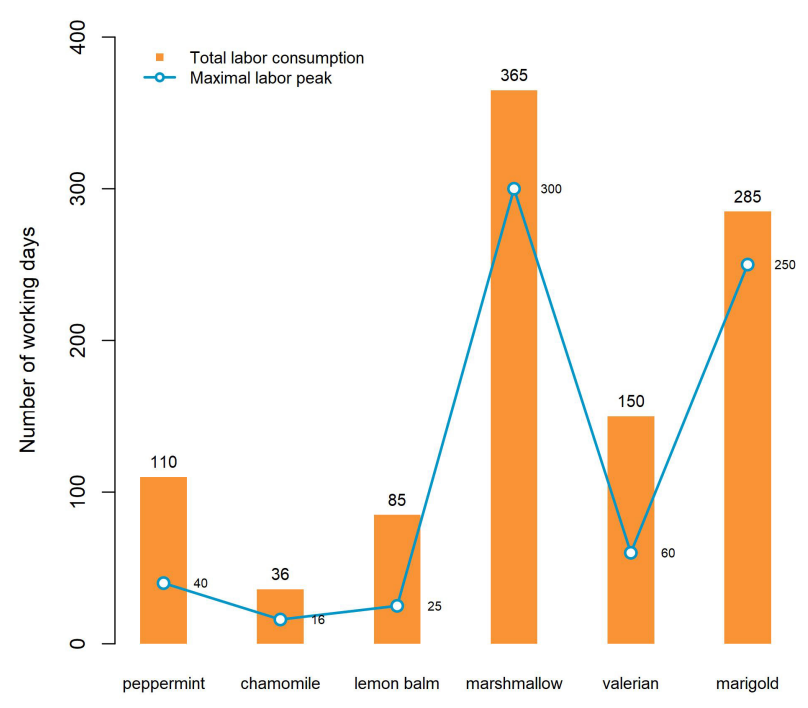

Fig. 2. The labor consumption with estimated maximal peak of labor engaged in cultivation of six medicinal plants in Serbia

plant cultivation costs with wild-craft collector's lead to the conclusion that the second one is much more profitable if high-quality raw material of plant of interest is abundant in nature (Sheldon et al., 1997). Collector, contrary to the field producer, does not have to rent the land and to perform necessary agricultural practices like obtaining of good quality seeds, seedlings production, deep plowing, fertilizing, soil preparation, planting, watering, hoeing, etc. (Dajić Stevanović and Pljevljakušić, 2015; Raghu, 2018). Nevertheless, cultivation can provide tonal amounts of first-class genetically superior raw material harvested at technological maturity, adequately dried, and properly processed. Since these requirements can hardly be met by wildcrafting, cultivation finds its place in the market. Furthermore, due to over-exploitation, certain habitats are devastated and consequently, protection regulations are issued, which favors cultivation as an instrument for conservation (Chen et al., 2016; Schippmann et al., 2003). Cultivation provides the opportunity to use new techniques to solve problems encountered in the production of medicinal plants, such as toxic components, pesticide contamination, low contents of active ingredients, and the misidentification of botanical origin (Raina et al., 2011).

The aim of this paper is to critically observe the relationship between production costs and profits in the field production of most commonly cultivated medicinal plants in Serbia. The authors have used long term production data to derive conclusions on this cost-benefit analysis. The special ambition of this analysis was to clarify the structure and scope of costs per hectare as a guide for future producers. Lack of information on labor necessity can lead to postponement or interruption of production.

\section{MATERIALS AND METHODS}

\subsection{Locality data}

All data were collected in South Banat (Serbia) during 19992019 cultivation period. Data for peppermint, chamomile, lemon balm and pot marigold have been collected from the medicinal plants production sector of the Institute for Medicinal Plants Research „Dr. Josif Pančić" at Pančevo (N 44.872162, E 20.699931, $81 \mathrm{~m}$ a.s.l., soil type humogley). Data for production analysis of marwhmallow cultivation was collected at Banatsko Novo Selo (N 44.956636, E 20.747762, 91 m a.s.1., soil type carbonated chernozem), while for valerian cultivation at Dubovac (N 44.782220, E 21.190558, 65 m a.s.l., soil type humofluvisol). All plants were harvested in the full technological maturity. Harvested plant material was subsequently dried in an industrial dryer at proper temperatures for each kind of raw material.

\subsection{Material}

Material costs include the costs of seeds and fertilizers. Seed and stolone prices are taken from the price list of the Institute for Medicinal Plants Research „Dr. Josif Pančić, and fertil- 
Table 1. Production calculation of the peppermint (Mentha x piperita) cultivation

\begin{tabular}{lcrrr}
\hline Description & Unit $^{\mathrm{a}}$ & $\begin{array}{r}\text { Value } \\
\text { per ha }\end{array}$ & $\begin{array}{r}\text { Price } \\
{[€]}\end{array}$ & $\begin{array}{r}\text { Total } \\
(€ / \mathrm{ha})\end{array}$ \\
\hline $\begin{array}{l}\text { A Production value } \\
\text { 1. Peppermint leaf yield }\end{array}$ & $\mathrm{kg}$ & 2500 & 2 & 5000 \\
Total A & & & & 5000 \\
\hline
\end{tabular}

\section{B Costs}

I Machinery

1. Fallow $15-20 \mathrm{~cm}$

w.d. $\quad 0.2$

2. Tillage $30 \mathrm{~cm}$

w.d. $\quad 0.5$

3. Fertilization $(2 \times)$

w.d. $\quad 0.2$

4. Soil shredding

w.d. $\quad 0.3$

5. Furrow opening

w.d.

0.3

6. Planting

w.d. $\quad 0.3$

7. Inter-row cult. $(2 \times)$

w.d. $\quad 0.4$

8. Harvesting $(2 \times)$

w.d. $\quad 0.25$

9. Fresh biomass transport

w.d. $\quad 0.2$

Total I

2.65

90

238.5

II Material

1. Fertilization (basic)

2. Fertilization

(supplem.)

$\mathrm{kg}$

500

0.4

200

Total II

$\mathrm{kg}$

300

0.3

90

290

III Labor

1. Stolone dig. \& plan.

w.d. $\quad 40$

2. Weeding

w.d. 25

3. Harvesting

w.d. 20

4. Drying and processing

w.d. 25

Total III

110

15

1650

IV Drying

1. Gas consumption $\quad \mathrm{m}^{3} \quad 5000$

\begin{tabular}{llll} 
Total IV & 5000 & 0.25 & 1250 \\
\hline
\end{tabular}

Total B (I+II+III+IV) 3428.5

Profit (A-B)

1571.5

a Abbreviation w.d. stands for working day.

izer prices are considered globally universal with minimal fluctuations. The costs of seedling production are included in fieldwork under labor costs. This survey comprises six plants that are commonly grown in the Serbian climate. Those plant species are peppermint (Mentha $\times$ piperita), chamomile (Chamomilla recutita), lemon balm (Melissa officinalis), marshmallow (Althaea officinalis), valerian (Valeriana officinalis), and marigold (Calendula officinalis).

\subsection{Labor data}

Workers on the plots of cultivated medicinal plants are hired as needed. The labor population originated from the Pančevo municipality and consisted mainly of women (80\%) ranging in age from 50 to 64 . Workers were engaged in three classes of work such as fieldwork (seedling production, planting, and
Table 2. Production calculation of the chamomile (Chamomilla recutita) cultivation

\begin{tabular}{|c|c|c|c|c|}
\hline Description & Unit $^{\mathrm{a}}$ & $\begin{array}{l}\text { Value } \\
\text { per ha }\end{array}$ & $\begin{array}{r}\text { Price } \\
{[€]}\end{array}$ & Total \\
\hline
\end{tabular}

$\begin{array}{lllrr}\begin{array}{l}\text { A Production value } \\ \text { 1. Chamomile flower }\end{array} & \mathrm{kg} & 450 & 5 & 2250 \\ \begin{array}{l}\text { head } \\ \text { 2. Chamomile pulvis }\end{array} & \mathrm{kg} & 250 & 2.5 & 625 \\ \text { Total A } & & & & 2875\end{array}$

B Costs

I Machinery

1. Fallow $15-20 \mathrm{~cm} \quad$ w.d. 0.2

2. Tillage $25 \mathrm{~cm} \quad$ w.d. $\quad 0.4$

3. Soil shredding w.d. 0.14

4. Rolling $(2 \times) \quad$ w.d. $\quad 0.17$

5. Sowing w.d. 0.2

6. Fertilization w.d. 0.1

7. Harvesting w.d. 0.35

8 Fresh biomass $\quad$ w.d. 0.1

transport

Total I

$\begin{array}{lll}1.66 & 90 & 149.4\end{array}$

II Material

$\begin{array}{lllll}\text { 1. Seed } & \mathrm{kg} & 20 & 8 & 160\end{array}$

2. Fertilization $\quad \mathrm{kg} \quad 100 \quad 0.3 \quad 30$

Total II

III Labor

\begin{tabular}{llrrr} 
1. Weeding & w.d. & 5 & & \\
2. Dryer service & w.d. & 16 & & \\
3. Processing & w.d. & 15 & & \\
Total III & & 36 & 15 & 540 \\
\hline
\end{tabular}

IV Drying

1. Gas consumption $\quad \mathrm{m}^{3} \quad 1300$

Total IV 1300

\begin{tabular}{ll} 
Total B (I+II+III+IV) & 1204.4 \\
\hline Profit (A-B) & 1670.6
\end{tabular}

a Abbreviation w.d. stands for working day.

weeding), dryer service (feeding, overturning and retrieval), and processing (superfluous parts of drugs removal). The working wage in the observed period was approximately 15 $€ /$ day. This price was used as a standard for labor cost calculation.

\subsection{Facilities, fuel and gas}

A Belarus 1221 tractor with appropriate attachments was used for soil preparation, while for lighter operations IMT 560 tractor has been employed. The price of the fuel used for further calculations was $1 € / \mathrm{L}$. The costs of using the machinery are calculated over the price of one working day (w.d.) of the machine. The price of the work of the machine for work of 8 hours plus the per diem for the tractor driver was calculated as $90 €$. Different levels in the difficulty of the operation in soil preparation were evaluated differently $(0.1-0.4$ w.d.). Owning a tractor was implied. A specialized harvester (Europrima d.o.o., Serbia) was used to harvest chamomile. An improvised 
root-digging tool was used to extract marshmallow roots. Two types of industrial dryers (floor and tunnel) were used equally in the postharvest production. The fuel for the production of thermal energy was natural gas (price $0.25 € / \mathrm{m}^{3}$ ).

\subsection{Data presentation}

Data are presented in a tabular manner with derived summarized descriptive statistics presented in pie-charts and one bar-chart. All data are estimated average values for 20-years field production. For all observed crops, except lemon balm, cost-benefit analyses of the cultivation prodaction were estimated only for first year of cultivation. Although some of them are perennial (peppermint, marshmallow and valerian), we considered as convinient to present the analysis in a one-year cycle due to several aspects of the nature of their cultivation.

\section{RESULTS AND DISCUSSION}

\subsection{Peppermint}

Mint propagation is performed by planting stolons (prostrate underground stems) in open furrows and subsequent covering with soil. Planting is a labor-intensive operation that involves the manual laying of stolons, which increases labor costs to an estimated 40 w.d. (Table 1). Since it is a thermophilic plant species, whose period of technological maturity for harvest coincides with the intensive growth of the most noxious weeds, weeding operations requires the engagement of the additional labor cca. 25 w.d. Moreover, harvesting is done by mower, but collecting of fresh biomass is usually manual and we estimate that this process requires about 10 workers per hectare. Considering that in a year with normal precipitation values, two mint harvests can be expected, the approximate cost of labor is estimated at $20 \mathrm{w} . \mathrm{d}$. Share of drying costs in total cost is the highest ( $37 \%$ ) compared to all other observed crops (Figure 1).

By reducing this cost, much higher profitability of production could be achieved, but it is extremely difficult to achieve a high-quality raw material of mint leaves by natural drying. Taking into account the high values of labor consumption, mint is certainly a labor-intensive crop, but comparing this cost (110 w.d) with the amount of labor incorporated in the costs of marshmallow, and marigold (365 w.d. and 285 w.d., respectively) we may conclude that peppermint is a mediumdemanding culture, at least as far as the engagement of the labor is concerned (Figure 2).

The production value of peppermint leaf has been estimated through a yield of $2500 \mathrm{t} / \mathrm{ha}$ and the price of $2 €$ per kilogram of dry raw material. The yield data are in agreement with previously published studies (Hornok, 1990; Dachler and Pelzmann, 1999; Kišgeci et al., 2009; Stepanović, 1998). Analyzing our data of costs to establish peppermint plantation with the literature data must be careful and adapted to the specific case. For instance, Wilson et al. (2011) have reported the initial cost of peppermint plantation establishment of $\$ 3360$, but this calculation included stolone purchase, fixed costs, and insecticide application. On the other hand, Mihajlov et al. (2015) calculated the profit of $1569 €$ and $8125 €$ for the first and second years of cultivation, respectively. From our experience, mint plants do not form an adequate habitus in the second year due to soil compaction and energy consumption for underground reproduction. Therefore, in our field practice, we replant the plantation within the crop rotation every year ensuring good plant growth and reduced weeds pressure. Nevertheless, similar to our findings Kumar et al. (2011) also reported that in operational cost, the maximum share was of hired labor.
Table 3. Production calculation of the lemon balm (Melissa officinalis) cultivation

\begin{tabular}{|c|c|c|c|c|}
\hline Description & Unit $^{\mathrm{a}}$ & $\begin{array}{l}\text { Value } \\
\text { per ha }\end{array}$ & $\begin{array}{r}\text { Price } \\
{[€]}\end{array}$ & $\begin{array}{r}\text { Total } \\
(€ / \text { ha) }\end{array}$ \\
\hline \multicolumn{5}{|l|}{ A Production value } \\
\hline 1. Lemon balm leaf yield $1^{\text {st }}$ & $\mathrm{kg}$ & 1000 & 2.2 & 2200 \\
\hline 2. L. balm leaf yield $2^{\text {nd }}-5^{\text {th }}$ & & 2500 & 2.2 & 5500 \\
\hline Total A $1^{\text {st }}$ & & & & 2200 \\
\hline Total A $2^{\text {nd }}-5^{\text {th }}$ & & & & 5500 \\
\hline
\end{tabular}

B Costs

I Machinery

1. Fallow $15-20 \mathrm{~cm}^{\mathrm{b}}$

2. Tillage $30 \mathrm{~cm}^{\mathrm{b}}$

3. Fertilization $(2 \times)^{b}$

w.d. $\quad 0.2$

4. Soil shredding ${ }^{\mathrm{b}}$

w.d. $\quad 0.5$

5. Furrow opening ${ }^{b}$

w.d. $\quad 0.2$

6. Planting ${ }^{\mathrm{b}}$

w.d. $\quad 0.3$

w.d. $\quad 0.2$

7. Inter-row cult. $(2 \times)$

w.d. $\quad 0.3$

w.d. $\quad 0.4$

8. Harvesting

w.d. $\quad 0.6$

9. Fresh biomass transport w.d. 0.2

Total I $1^{\text {st }}$

Total I $2^{\text {nd }}-5^{\text {th }}$

$2.9 \quad 90 \quad 261$

II Material

1. Seed ${ }^{b}$

2. Fertilization (basic) ${ }^{b}$

3. Fertilization (supplem.)

$\begin{array}{lll}\mathrm{kg} & 500 \quad 0.4\end{array}$

130

39

Total II $1^{\text {st }}$

kg $\quad 200 \quad 0.3$

Total II $2^{\text {nd }}-5^{\text {th }}$

III Labor

1. Seedlings production ${ }^{b}$

w.d. $\quad 20$

2. Planting ${ }^{\mathrm{b}}$

w.d. $\quad 20$

3. Weeding

w.d.

25

4. Harvesting

5. Drying and processing

w.d.

10

Total III $1^{\text {st }}$

w.d.

10

85

Total III $2^{\text {nd }}-5^{\text {th }}$

45

15

1275

IV Drying

1. Gas consumption

Total IV $1^{\text {st }}$

\begin{tabular}{|c|c|c|c|}
\hline Total IV $2^{\text {nd }}-5^{\text {th }}$ & 4000 & 0.25 & 1000 \\
\hline Total B (I+II+III+IV) $1^{\text {st }}$ & & & 2335 \\
\hline Total B (I+II+III+IV $) 2^{\text {nd }}-5^{\text {th }}$ & & & 1843 \\
\hline Profit (A-B) $1^{\text {st }}$ & & & -135 \\
\hline Profit $(A-B) 2^{\text {nd }}-5^{\text {th }}$ & & & 3657 \\
\hline
\end{tabular}

a Abbreviation w.d. stands for working day.

${ }^{\mathrm{b}}$ Costs that are present only in the year of plantation establishment.

\subsection{Chamomile}

The cultivation of chamomile is most similar to the cultivation of conventional field crops for several reasons. It is an annual 
species, which forms a rosette in the fall, and blooms in the spring of the following year when it completes the vegetation. It is sown directly on the rolled surface. Reducing the pressure of weed flora in the chamomile cultivation is usually provided by crop rotation with wheat in full agricultural techniques. Although, chamomile blooms very early in the spring, when aggressive field weeds have not sprouted yet, sometimes hoeing is desirable. The most noxious weeds in the chamomile cultivation are common poppy (Papaver rhoeas), charlock mustard (Sinapis arvensis), creeping thistle (Cirsium arvense) and spontaneously emerged plants of the previous crop such as wheat (Triticum aestivum). Harvesting is done with specialized harvesters, and the harvesting campaign lasts from 15-20 days. Such a short harvest period is a limiting factor in terms of quantities that can be dried well, which requires careful planning of sowing areas for this crop. For drying chamomile flowers, it is necessary to have large drying capacities, since it must be spread out in a thin layer due to the high percentage of moisture $(90 \%)$. Post-harvest processing is performed on specialized machines for cutting flower stalks and pulvis sifting.

The production value of chamomile cultivation per hectare has been estimated in Table 2 through two products, the yield of flower heads $(450 \mathrm{~kg})$ and yield of pulvis $(250 \mathrm{~kg})$, with different market prices ( $5 €$ and $2.5 €$, respectively). Our estimated production value and yields are not always in accordance with the literature data. Marković et al. (2014) reported a total production value of $2545 € /$ ha, while Ivanović et al. (2014) estimated total products yield to nearly $900 \mathrm{~kg} / \mathrm{ha}$. Economic analysis of chamomile cultivation in Turkey showed that total variable costs are in the range of 1504-2638 $€ /$ ha and an estimated net profit of $1908-8400 € /$ ha, depending on cultivar, row spacing, and sowing time (Arslan et al., 2019). Nevertheless, the fact that the total yields of flower heads and pulvis together are around $700 \mathrm{~kg}$ per hectare has been confirmed by many literature references (Dachler and Pelzmann, 1999; Jánosné, 1990; Kišgeci, 2002; Stepanović, 1998), while Bernáth and Németh (2005) estimated total flower production of 100 $500 \mathrm{~kg} / \mathrm{ha}$.

By analyzing the costs of chamomile cultivation, we can conclude that labor costs share is relatively high ( $45 \%)$ even if labor engagement in working days (36 w.d.) is the lowest among the other cultivated species (Figure 1 and 2). The reason for this discrepancy lies in the disproportion of the total costs of chamomile in relation to other observed crops. Drying costs in chamomile cultivation are among the highest since the drying ratio of flowerheads in the bulk raw material from the field is about 1:10. Although the cost review shows that labor engagement in chamomile cultivation is the lowest of all observed plants, this calculation lacks in fixed costs analysis. In order to achieve high automation of field production of chamomile, it is necessary to invest in specialized harvesters, large drying capacities, and machines for post-harvest processing. Such investments can only pay off in production on over 10 ha (Grozdanić, N. Euro Prima d.o.o - personal communication).

\subsection{Lemon balm}

Unlike for other observed crops, an overview of lemon balm cultivation costs has been presented in a two-year manner considering that in the first year, due to the high costs of plantation establishment, production is not profitable and that this is a perennial crop that remains on the same plot for several years. Seedlings production and planting are, besides weeding, most labor-demanding operations, which are present only in the year of plantation establishment (Table 3).

Due to the convenience of presentation, only the costs of the first year of cultivation are presented in Figure 1, so this graph
Table 4. Production calculation of the marshmallow (Althea officinalis) cultivation

\begin{tabular}{lrrrr}
\hline Description & Unit $^{\mathrm{a}}$ & $\begin{array}{r}\text { Value } \\
\text { per ha }\end{array}$ & $\begin{array}{r}\text { Price } \\
{[€]}\end{array}$ & $\begin{array}{r}\text { Total } \\
(€ / \text { ha })\end{array}$ \\
\hline $\begin{array}{l}\text { A Production value } \\
\text { 1. Marshmallow root } \\
\text { cube yield }\end{array}$ & $\mathrm{kg}$ & 1500 & 7 & 10500 \\
$\begin{array}{l}\text { Total A } \\
\text { The }\end{array}$ & & & & \\
\end{tabular}

B Costs

I Machinery

1. Fallow $15-20 \mathrm{~cm} \quad$ w.d. $\quad 0.2$

2. Tillage $30 \mathrm{~cm} \quad$ w.d. $\quad 0.5$

3. Fertilization $(2 \times) \quad$ w.d. $\quad 0.2$

$\begin{array}{lll}\text { 4. Soil shredding } \quad \text { w.d. } & 0.3\end{array}$

$\begin{array}{lll}\text { 5. Inter-row cult. }(2 \times) & \text { w.d. } & 0.4\end{array}$

6. Sowing

7. Root digging

w.d. $\quad 0.3$

8. Fresh biomass transport

w.d. $\quad 0.6$

Total I

w.d. $\quad 0.2$

II Material

1. Seed

2. Fertilization (basic)

3. Fertilization

(supplem.)

Total II

$2.7 \quad 90$

III Labor

1. Weeding

2. Root digging

3. Peeling and chopping

4. Drying and processing

$\begin{array}{llll}\mathrm{kg} & 6 & 110 & 660\end{array}$

Total III

$\mathrm{kg} \quad 500 \quad 0.4$

200

kg $\quad 200 \quad 0.3$

\section{Drying}

1. Gas consumption

Total IV

\begin{tabular}{ll}
\hline Total B (I+II+III+IV) & 6938 \\
\hline Profit (A-B) & 3562 \\
\hline a Abbreviation w.d. stands for working day.
\end{tabular}

a Abbreviation w.d. stands for working day.

should be taken with a grain of salt, where an idea of the share of costs in the subsequent years can be observed in Table 3. We estimated the costs in the first year at $2335 €$, while the costs in the subsequent years is estimated at 1843 $€$. This consequently causes a discouraging negative profit in the year of establishment $(-135 €)$, while in the second and subsequent years, thanks to increased leaf yield and reduced planting costs, a profit of $3657 €$ per hectare can be expected Even though labor consumption determines the profitability of lemon balm cultivation, this crop belongs to the group of less labor-demanding species among all observed medicinal plants in this study (Figure 2). In general, the cost of maintaining a lemon balm plantation after the first year can be equated with the cost of maintaining a peppermint plantation. This 
Table 5. Production calculation of the valerian (Valeriana officinalis) cultivation

\begin{tabular}{lrrrr}
\hline Description & Unit $^{\mathrm{a}}$ & $\begin{array}{r}\text { Value } \\
\text { per ha }\end{array}$ & $\begin{array}{r}\text { Price } \\
{[€]}\end{array}$ & $\begin{array}{r}\text { Total } \\
(€ / \mathrm{ha})\end{array}$ \\
\hline $\begin{array}{l}\text { A Production value } \\
\text { 1. Valerian root yield }\end{array}$ & $\mathrm{kg}$ & 1500 & 5 & 7500 \\
Total A & & & & 7500
\end{tabular}

\section{B Costs}

I Machinery

1. Fallow $15-20 \mathrm{~cm}$

w.d. $\quad 0.2$

2. Tillage $30 \mathrm{~cm}$

w.d.

0.5

3. Fertilization $(2 \times)$

w.d.

0.2

4. Soil shredding

w.d.

0.3

5. Planting

w.d.

0.3

6. Inter-row cult. $(2 \times)$

w.d.

0.4

7. Root digging

w.d.

0.6

8. Fresh biomass transport

w.d.

Total I

2.7

90 243

\section{Material}

$\begin{array}{llrrr}\text { 1. Seed } & \mathrm{kg} & 0.5 & 130 & 65 \\ \begin{array}{l}\text { 2. Fertilization (basic) } \\ \text { 3. Fertilization }\end{array} & \mathrm{kg} & 500 & 0.4 & 200 \\ \begin{array}{l}\text { (supplem.) } \\ \text { Total }\end{array} & \mathrm{kg} & 200 & 0.3 & 60\end{array}$

Total II

\section{Labor}

$\begin{array}{lllll}\text { 1. Seedlings production } & \text { w.d. } & 20 & & \\ \text { 2. Planting } & \text { w.d. } & 20 & & \\ \text { 3. Weeding } & \text { w.d. } & 25 & & \\ \text { 4. Root collecting } & \text { w.d. } & 20 & & \\ \text { 5. Washing and cutting } & \text { w.d. } & 60 & & \\ \text { 6. Drying and } & \text { w.d. } & 5 & & \\ \text { processing } & & 150 & 15 & 2250 \\ \text { Total III } & & & \end{array}$

\section{Drying}

1. Gas consumption $\quad \mathrm{m}^{3} \quad 1200$

Total IV 1200
300

Total B (I+II+III+IV)

3118

Profit (A-B)

4382

a Abbreviation w.d. stands for working day.

would be one of the most promising medicinal plant crops if the market for leaf raw material was stable for a long period. The problem arises in years when the market is saturated and when there is no demand for lemon balm leaf.

Similar lemon balm leaf yields as in our survey have been reported previously, where yields ranged from $600-1000 \mathrm{~kg} / \mathrm{ha}$ and $1500-3000 \mathrm{~kg} / \mathrm{ha}$ in the first and second year of cultivation, respectively (Filipović and Ugrenović, 2019; Hornok and Lenchés, 1990a; Kišgeci, 2002; Stepanović, 1998). On the other hand, Bomme et al. (2013) reported much higher yields from $1900-4000 \mathrm{~kg} / \mathrm{ha}$ and $2000-4500 \mathrm{~kg} / \mathrm{ha}$, in the first and second year of cultivation, respectively. This discrepancy may be due to climatic, genetic, pedological characteristics or, most likely, levels of agronomic inputs.

\subsection{Marshmallow}

The benefit of marshmallow cultivation is one of the trickiest questions in non-scientific literature and media. Earnings are often overestimated through simply multiplying the root yield by the market price of the raw material. The fact that raw material traded on the market is 'dry cube' produced from peeled and chopped roots is most often ignored. While the ratio of fresh biomass to dry raw material in most root-drug medicinal plants is around $3: 1$, in marshmallow this ratio is 10:1 due to root peeling and cutting off the useless upper part of the root. The truth is that production value per hectare of cultivated marshmallow exceeds $10000 €$ (Table 4), but according to our findings about $79 \%$ of marshmallow total costs are reserved for labor (Figure 1). New producers should be aware that they need 365 w.d. for the successful production of marshmallow cube from one hectare (Figure 2). We also estimated that the highest labor consumption per operation was 300 w.d. (root peeling and chopping). Fortunately, it is not necessary to dig up and peel all the roots at once. The root harvest can be extended to several months in which there is no frost, and also the dug fresh root can be stored for a longer period until peeling in a cold place. In this way, it is possible to disperse the process to a smaller number of workers over a longer period.

Our best estimate of net profit per hectare is around $3500 €$, but due to the large consumption of labor and complicated organization, a small number of producers dared to grow marshmallow on an area of more than 0.1 ha. Cultivation is usually done as a side activity in large families, where the cost of labor remains in-house as income.

Similar yields of dry marshmallow root cube have been reported previously (Kišgeci et al., 2009; Lenchés, 1990a; Stepanović, 1998). Since, to the best of our knowledge, no literature source has reported a detailed analysis of labor consumption in the marshmallow production, in this paper we aimed to emphasize the significant share of the labor engaged in peeling and chopping roots.

\subsection{Valerian}

Valerian is another root-drug medicinal plant with an estimated high production value of about $7500 €$ (Table 5). The high price of dried valerian root is a consequence of the very difficult adjustment of the producer to meet the three necessary conditions for cultivation, such as fertile soil of lighter mechanical composition, sufficient amount of running water, and the availability of labor. Furthermore, the market for this raw material is sometimes very limited and a good recommendation would be to ensure secure placement before establishing a plantation. Besides marshmallow and marigold, valerian is one of the most labor-demanding medicinal crops (Figure 1). About $40 \%$ of the total labor costs belong to washing and chopping the roots (Figure 2). Although its successful cultivation requires a lot of experience and despite the fact that it is difficult to organize the workforce for chopping and washing, this is one of the most profitable crops for which there is a constant demand on the market. In order to successfully remove soil particles, the rhizome must be cut into several smaller parts, which allows the water to remove dirt. Since removing soil particles from root after drying is inconvenient, washing is a necessary step in the production of quality raw material that meets the quality criteria of the $5 \%$ acid-insoluble ash content (Ph.Eur.8.0., 2014). Therefore, the consumption of 60 w.d. of labor for this operation per hectare of cultivated valerian is rational and justified with the high price of raw material. Among other labor demanding operations, seedlings production takes about 20 w.d. This operation is very sensitive 
Table 6. Production calculation of the marigold (Calendula officinalis) cultivation

\begin{tabular}{|c|c|c|c|c|}
\hline Description & Unit $^{\mathrm{a}}$ & $\begin{array}{l}\text { Value } \\
\text { per ha }\end{array}$ & $\begin{array}{r}\text { Price } \\
{[€]}\end{array}$ & $\begin{array}{r}\text { Total } \\
(€ / \text { ha })\end{array}$ \\
\hline \multicolumn{5}{|l|}{ A Production value } \\
\hline 1. Marigold flower yield & $\mathrm{kg}$ & 1200 & 5 & 6000 \\
\hline Total A & & & & 6000 \\
\hline \multicolumn{5}{|l|}{ B Costs } \\
\hline \multicolumn{5}{|l|}{ I Machinery } \\
\hline 1. Fallow $15-20 \mathrm{~cm}$ & w.d. & 0.2 & & \\
\hline 2. Tillage $30 \mathrm{~cm}$ & w.d. & 0.5 & & \\
\hline 3. Fertilization $(2 \times)$ & w.d. & 0.2 & & \\
\hline 4. Soil shredding & w.d. & 0.3 & & \\
\hline 5. Sowing & w.d. & 0.3 & & \\
\hline 6. Inter-row cult. $(2 \times)$ & w.d. & 0.4 & & \\
\hline $\begin{array}{l}\text { 8. Fresh biomass } \\
\text { transport }\end{array}$ & w.d. & 0.2 & & \\
\hline Total I & & 2.1 & 90 & 189 \\
\hline \multicolumn{5}{|l|}{ II Material } \\
\hline 1. Seed & $\mathrm{kg}$ & 8 & 35 & 280 \\
\hline 2. Fertilization (basic) & $\mathrm{kg}$ & 300 & 0.4 & 120 \\
\hline $\begin{array}{l}\text { 3. Fertilization } \\
\text { (supplem.) }\end{array}$ & $\mathrm{kg}$ & 200 & 0.3 & 60 \\
\hline Total II & & & & 460 \\
\hline \multicolumn{5}{|l|}{ III Labor } \\
\hline 3. Weeding & w.d. & 25 & & \\
\hline 4. Flower picking & w.d. & 250 & & \\
\hline $\begin{array}{l}\text { 6. Drying and } \\
\text { processing }\end{array}$ & w.d. & 10 & & \\
\hline Total III & & 285 & 15 & 4275 \\
\hline \multicolumn{5}{|l|}{ IV Drying } \\
\hline 1. Gas consumption & 3 & 2000 & & \\
\hline Total IV & & 2000 & 0.25 & 500 \\
\hline Total B (I+II+III+IV) & & & & 5424 \\
\hline Profit (A-B) & & & & 576 \\
\hline
\end{tabular}

${ }^{a}$ Abbreviation w.d. stands for working day.

considering that the summer production of seedlings in open beds is cheaper than the production in a heated greenhouse. The problem arises if the seedlings develop too much in the fall and accept the year of sowing as the first year of vegetation. Such plants develop a flowering stem in the following year and thus reduce the root yield. This phenomenon can be overcome by a high density of plants in the beds or by sowing in the spring in a heated greenhouse. Attention should also be paid to the dormancy of seeds whose germination decreases rapidly by spring if not stored adequately. Seedlings production is followed by planting operation, which is also recognized as labor-demanding (20 w.d). Valerian is usually harvested with potato diggers and other related farm tools, but root collection is most commonly done by hand. Thus, this operation also requires significant labor engagement (20 w.d.).

Our valerian dry root yield estimation of about $1.5 \mathrm{t} / \mathrm{ha}$ is in accordance with previously published data (Dachler and Pelz- mann, 1999; Douglas et al., 1996; Jánosné, 1978; Kleitz et al., 2003; Wiśniewski et al., 2016; Hornok and Lenchés, 1990b). On the other hand, some literature data estimated a much higher root yield of about 5-6 t/ ha (Dambrauskiene et al., 2010; Morteza et al., 2010). Since high water requirement generally is an accepted condition for valerian cultivation (Jánosné, 1978), disagreements in root yield reports could be a consequence of combined irrigation and fertilization treatments. In our assessment of root yield, we were guided by a multi-year average of dry farming.

\subsection{Marigold}

The establishment of the marigold plantation is done by direct sowing, which makes this plant species similar to conventional field crops. The biggest problem in obtaining quality raw material is the harvest, which is done by hand. There have been several attempts to automate harvesting with specially modified harvesters for this purpose (Jäntschi et al., 2008; Veselinov et al., 2014; Willoughby et al., 2000), but knowing the market situation, these attempts have not resulted in raw material of acceptable quality. Therefore, in our marigold cultivation cost estimation flower picking is far the most labor demanding process ( 250 w.d). Although marigold flower heads handpicking as an operation regarding maximum consumption of labor comes in second place, just after peeling marshmallow roots (Figure 2), this process is prolonged into four months (May-August), which is the duration of the flowering phase. Weeding and postharvest processing of marigold are processes whose labor requirements are similar to those of other observed species in this study.

Our estimation of marigold flower yields is in accordance with previously published data. Most of the papers dealing with marigold reported yields of dry flowerheads in the range of 750 - 1500 kg (Dachler and Pelzmann, 1999; Lenchés, 1990b; Stepanović, 1998; Kišgeci, 2002). Based on an estimated yield of $1200 \mathrm{~kg} /$ ha our best projection of total production value is $6000 €$ (Table 6). Nevertheless, the total labor costs are so great that only about $10 \%$ of the profits remain from this value. In other words, in order to earn $576 €$, a producer must be willing to pay marigold flower pickers around $3750 €$. For this reason, marigold, similar to marshmallow, is grown in small areas within households where labor per diems remain as inhouse profit. Moreover, the market price of this raw material is also significantly affected by the import of low-cost raw material of marigold flowers from African countries, where the daily wage is significantly lower than in Europe.

Automation of harvesting in the form of a combine that harvests a flower of high output quality would greatly increase the profitability of marigold production.

\section{CONCLUSION}

Regarding the level of profitability of cultivation of the six observed medicinal plants, we can conclude that valerian is the most profitable with an estimated profit of over $4000 € /$ ha Next best earning plants are lemon balm and marshmallow with about $3500 € /$ ha, while the income from peppermint and chamomile is more than twice lower and is around $1500 € /$ ha The lowest profit is realized by cultivating marigold (about 600 $€ /$ ha) due to the high labor consumption on the flower picking operation. In terms of labor consumption marshmallow, pot marigold and valerian are the most demanding with 365 , 285 and 150 working days per hectare, respectively. This does not mean that the producer has to hire such a large number of workers at the same time, but it indicates the scope of human labor engagement in obtaining the final product. Peppermint, chamomile and lemon balm are less labor-intensive crops with 110, 36 and 85 working days per hectare, respectively. The general conclusion of this observation of the profitability of 
growing medicinal plants would be that the producer must be aware of the costs and scope of labor engagement he expects per unit area before embarking on the calculation of production. The numerical values of the purchase prices of raw materials and workers' per diems are current and most likely to be variable over time, so that subsequent recalculation is more than recommended.

\section{ACKNOWLEDGMENTS}

This work was supported by the Ministry of Education, Science and Technological Development of the Republic of Serbia (Contract No. 451-03-68/2020-14/200003).

\section{REFERENCES}

Arslan, D., Bayraktar, Ö. V., Temel, M. and Bayram, E. (2019). Economical analysis of chamomile (Matricaria recutita 1.) cultivars, flower yields which are obtained from different sowing times and row spacing, Tarim Bilimleri Dergisi Journal Of Agricultural Sciences 25: 129-136.

Bernáth, J. and Németh, E. (2005). Production of chamomilla (Matricaria recutita L.) in East and South european countries, in R. Franke and H. Schilcher (eds), Chamomile: Industrial Profiles, Boca Raton, FL, USA: CRC Press, chapter 5, pp. 119 132.

Bomme, U., Honermeier, B., Hoppe, B., Kittler, J., Lohwasser, U. and Marthe, F. (2013). Melisse (Melissa officinalis 1.) [in german], in B. Hoppe (ed.), Handbuch Arznei- und Gewurzpflanzenbaus, Vol. 5, Bernburg, Saluplanta, p. 151-173.

CCIS report (2018). Chamber of Commerce and Industry of Serbia.

Chen, S.-L., Yu, H., Luo, H.-M., Wu, Q., Li, C.-F. and Steinmetz, A. (2016). Conservation and sustainable use of medicinal plants: problems, progress, and prospects, Chinese Medicine 11(1): 37

Cunningham, A. (1994). Management of medicinal plant resources, in J. Seyani and A. Chikuni (eds), Proceedings of the 13th Plenary Meeting of AETFAT, Vol. 1, p. 173-189.

Dachler, M. and Pelzmann, H. (1999). Arznei- und Gewürzpflanzen. Anbau, Ernte, Aufbereitung, Österreichisch Agrarverlag, Klostrerneuburg.

Dajić Stevanović, Z. and Pljevljakušić, D. (2015). Challenges and decision making in cultivation of medicinal and aromatic plants, in A. Máthé (ed.), Medicinal and Aromatic Plants of the World: Scientific, Production, Commercial and Utilization Aspects, Medicinal and Aromatic Plants of the World, Springer Netherlands, pp. 145-164.

Dambrauskiene, E., Zalatorius, V. and Viškelis, P. (2010). Influence of growing methods on valerian root yield and quality., Sodininkyste ir Daržininkyste 29(4): 85-91. Publisher: Lietuvos Sodininkystes ir Darzininkystes Institutas (Lithuanian Institute of Horticulture).

Douglas, J., Follett, J., Douglas, M. and Heaney, A. (1996). Effect of plant density on the production of valerian root, Acta Horticulturae 426: 375-379.

Filipović, V. and Ugrenović, V. (2019). Lemon balm (Melissa officinalis 1.) - Technology of cultivation and production cost estimate., in J. Subić, M. Jeločnik, B. Kuzman and A. J. Vasile (eds), Sustainable agriculture and rural development in terms of the Republic of Serbia strategic goals realization within the
Danube region - sustainability and multifunctionality, The Institute of Agricultural Economics \& Chamber of Commerce and Industry of Serbia, Belgrade Serbia, p. $794-810$.

Hornok, L. (1990). Peppermint [Borosmenta], in H. László (ed.), Cultivation and Processing of Medicinal Plants (Gyógynövények termesztése és feldolgozása) [in Hungarian], Mezőgazdasági Kiadó, Budapest, pp. 175-183.

Hornok, L. and Lenchés, O. (1990a). Lemon balm [Citromfú], in H. László (ed.), Cultivation and Processing of Medicinal Plants (Gyógynövények termesztése és feldolgozása) [in Hungarian], Mezőgazdasági Kiadó, Budapest, pp. 199-201.

Hornok, L. and Lenchés, O. (1990b). Valerian [Macskagyökér], in H. László (ed.), Cultivation and Processing of Medicinal Plants (Gyógynövények termesztése és feldolgozása) [in Hungarian], Mezőgazdasági Kiadó, Budapest, pp. 170-173.

Ivanović, S., Pajić, M. and Marković, T. (2014). Economic effectiveness of mechanized harvesting of chamomile, Economics of Agriculture

Jánosné, S. (1978). Macskagyökér (Valeriana officinalis), in H. László (ed.), Gyógynövények termesztése és feldolgozása (Growing and processing of herbs), Mezőgazdasági Könyvkiadó Vállalat, Budapest, pp. 152-157.

Jánosné, S. (1990). Chamomile [Kamilla], in H. László (ed.), Cultivation and Processing of Medicinal Plants (Gyógynövények termesztése és feldolgozása) [in Hungarian], Mezőgazdasági Kiadó, Budapest, pp. 234-239.

Jäntschi, L., Jäntschi, G. A., Balan, M. C., Duda, M. and Bolboaca, S. (2008). On about design and implementation of a harvester for French and English marigold, Bulletin UASVM, Horticulture 65(1): 192-197.

Kišgeci, J. (2002). Medicinal plants: cultivation, collecting and application, Partenon, Belgrade.

Kišgeci, J., Jelačić, S. and Beatović, D. (2009). Medicinal, aromatic, and spice plants [in Serbian], Faculty of Agriculture, Belgrade.

Kleitz, K., Wall, M., Falk, C., Martin, C., Guldan, S. and Remmenga, M. (2003). Yield potential of selected medicinal herbs grown at three plant spacings in New Mexico, HortTechnology 13(4): 631-636.

Kumar, S., Suresh, R., Singh, V. and Singh, A. K. (2011). Economic analysis of menthol mint cultivation in Uttar Pradesh A case study of Barabanki district, Agricultural Economics Research Review 24: 345-350.

Lange, D. (1998). Europe's medicinal and aromatic plants: their use, trade and conservation., TRAFFIC Europe.

Lenchés, O. (1990a). Marshmallow [Fehérmályva], in H. László (ed.), Cultivation and Processing of Medicinal Plants (Gyógynövények termesztése és feldolgozása) [in Hungarian], Mezőgazdasági Kiadó, Budapest, pp. 126-128.

Lenchés, O. (1990b). Pot marigold [Körömvirág], in H. László (ed.), Cultivation and Processing of Medicinal Plants (Gyógynövények termesztése és feldolgozása) [in Hungarian], Mezőgazdasági Kiadó, Budapest, pp. 228-230.

Marković, T., Ivanović, S. and Pajić, M. (2014). Costs and profit in chamomile production using weather put option, Custos e Agronegocio 10(2): 285-295. 
Mihajlov, L., Zlatkovski, V. and Ruzdik, N. M. (2015). Obtained yield and financial parameters of organically grown mint in the Republic of Macedonia, British Journal of Applied Science E Technology 10(4): 1-6.

Müller, J. and Heindl, A. (2006). Drying of medicinal plants, in R. Bogers, L. Craker and D. Lange (eds), Medicinal and aromatic plants - agricultural, commercial, ecological, legal, pharmacological and social aspects, Wageningen UR Frontis Series, Springer Netherlands, pp. 237-252.

Morteza, E., Akbari, G. A., Sanavi, S. A. M. M. and Farahani, H. A. (2010). Determination of the vegetative and reproductive characteristics of valerian (Valeriana officinalis L.) under sowing dates and planting densities in Iran, Journal of Medicinal Plants Research 4(10): 857-861. Publisher: Academic Journals.

Ph.Eur.8.0. (2014). European Pharmacopoeia 8.0., Council of Europe, Strasbourg Cedex, France.

Raghu, A. (2018). Cultivation of medicinal plants: Challenges and prospects, in A. Raghu, M. Amruth, K. Muhammed Kunhi, V. Raveendran and S. Viswanath (eds), Cultivation of Medicinal Plants: Challenges and Prospects, KSCSTE-Kerala Forest Research Institute, pp. 85-94.

Raina, R., Chand, R. and Sharma, Y. (2011). Conservation strategies of some important medicinal plants, International Journal of Medicinal and Aromatic Plants 1(3): 342-347.

Schippmann, U., Leaman, D. and Cunningham, A. (2006). A comparison of cultivation and wild collection of medicinal and aromatic plants under sustainability aspects, in R. Bogers, L. Craker and D. Lange (eds), Medicinal and Aromatic Plants, Vol. 17 of Wageningen UR Frontis Series, Springer Netherlands, pp. 75-95.

Schippmann, U., Leaman, D., Cunningham, A. and Walter, S. (2003). Impact of cultivation and collection on the conservation of medicinal plants: global trends and issues, Acta Horticulturae 676: 31-44.

Sheldon, J., Balick, M. and Laird, S. (1997). Medicinal Plants: Can Utilization and Conservation Coexist?, Vol. 12 of Advances in Economic Botany, New York Botanical Garden Pr Dept.

Small, E. (2004). The economic potential of medicinal plant production with particular reference to quebec, Biodiversity, National Program on Environmental Health, Ontario, Canada.

Stepanović, B. (1998). Production of medicinal plants [in Serbian], Institute for Medicinal Plants Research "Dr. Josif Pančić", Belgrade.

Veselinov, B., Adamović, D., Martinov, M., Višković, M., Golub, M. and Bojić, S. (2014). Mechanized harvesting and primary processing of Calendula officinalis 1. inflorescences, Spanish Journal of Agricultural Research 12(2): 329-337.

Vines, G. (2004). Herbal harvests with a future: towards sustainable sources for medicinal plants, Plantlife International, Wiltshire, UK.

Willoughby, R., Solie, J., Whitney, R., Maness, N. and Buser, M. (2000). A mechanical harvester for marigold flowers., Proceedings, ASAE Annu Int Meeting, Milwaukee, WI, USA, pp. 1-14.

Wilson, R., Marcum, D., Klonsky, K. and De Moura, R. (2011). Sample costs to establish a mint stand and produce peppermint oil, Technical report, University of California - cooperative extension.
Wiśniewski, J., Szczepanik, M., Kołodziej, B. and Król, B. (2016). Plantation methods effects on common valerian (Valeriana officinalis) yield and quality, The Journal of Animal $\mathcal{E}$ Plant Sciences 26(1): 177-184. 